\title{
Serummålinger av psykofarmaka - vet vi hva vi gjør?
}

\author{
Terapimonitorering av psykofarmaka har fått et betydelig omfang. For de fleste psykofarmaka er \\ det ikke etablert et definert terapeutisk område. Laboratoriene omgår dette ved å bruke begrepet \\ «referanseområde», som de fleste leger oppfatter som et ønskelig eller korrekt serumnivå. Leger \\ bør stole mer på sin kliniske vurdering enn på serumkonsentrasjonsmålinger.
}

Etter et oppslag i Dagens Medisin i februar 2009 om serummålinger og dosering av antipsykotika (1) forsøkte jeg å få i gang en debatt om terapimonitorering (Therapeutic Drug Monitoring, TDM) av psykofarmaka. Det viste seg å være vanskelig. Motinnleggene forsvarte dagens praksis med et påfallende fravær av dokumentasjon og faglige argumenter. Hvor omfattende bruken av serummålinger er, ble imidlertid dokumentert. Diakonhjemmet opplyste at de utfører over 100000 analyser hvert år (2). Vi kan kanskje gå ut fra at den andre store aktøren på dette markedet, St. Olavs hospital, utfører et tilsvarende antall analyser. Andre laboratorier tilbyr også slike tjenester, men i et mindre omfang. Hvis kostnad per analyse ligger på 200-300 kroner, dreier det seg om årlige helseutgifter som raskt begynner å nærme seg 100 millioner kroner. Er dette vel anvendte penger?

I utgangspunktet er det vanskelig å forstå at terapimonitorering av psykofarmaka har fått et slikt omfang. En forutsetning er at det finnes et definert terapiområde for medikamentet, dvs. et serumkonsentrasjonsintervall som kan knyttes til en terapeutisk respons hos et flertall av pasientene. Til tross for betydelig forskningsinnsats er et slikt terapiområde ikke etablert for det store flertallet av psykofarmaka (3-5).

\section{Referanseområde $\neq$ terapiområde}

Laboratoriene forsøker å omgå dette problemet ved å ty til et begrep fra en helt annen del av medisinen. De bruker begrepet «referanseområde» i stedet for «terapeutisk område». Referanseområde er tradisjonelt blitt brukt til å tallfeste et normalnivå for fysiologiske fenomener i en populasjon. Et referanseområde defineres oftest ut fra gjennomsnittsverdien i et stort antall målinger hos presumptivt normale eller friske individer med to standardavvik til begge sider, noe som vil inkludere $95 \%$ av populasjonen. Det er dette laboratoriene også har gjort for serumkonsentrasjoner av psykofarmaka. I mangel av effektmålinger foregir man at serumnivåer av psykofarmaka er et normalfordelt fysiologisk fenomen som i seg selv definerer et normaleller referanseområde.

Laboratoriene argumenterer først og fremst med at slike målinger er et nyttig hjelpemiddel ved f.eks. uventede bivirk- ninger og presiserer i litt ulik grad at serumkonsentrasjoner isolert ikke kan brukes som et mål på adekvat medisinering. Etter min oppfatning forstår de fleste leger begrepet «referanseverdi» på en helt annen måte, nemlig som et terapivindu som bør etterstrebes i behandlingen. Denne holdningen har fulgt med omdefineringen av referanseverdibegrepet fra et fysiologisk til et farmakologisk begrep. Min erfaring er at mange leger sender inn prøver uten annen hensikt enn å sjekke om serumkonsentrasjonene ligger innenfor «referanseområdet». Det betydelige omfanget denne virksomheten har fătt, mener jeg støtter denne antakelsen.

\section{Konsekvenser}

Får disse konsentrasjonsmålingene noen positive konsekvenser? Litium har et definert og smalt terapiområde. Selv om det ikke er formelt undersøkt, må det være rimelig å anta at terapimonitorering av litium øker muligheten for at serumkonsentrasjonen holder seg i terapiområdet og dermed reduserer risikoen både for toksiske doser og tilbakefall. Serummålinger kan avsløre at pasienten ikke tar medisinen sin. Det gjelder for alle medikamenter og kan være nyttig å vite.

Etter min erfaring kan tiltroen til serummålinger av psykofarmaka i gitte tilfeller også ha direkte negative konsekvenser for pasienten. Et ikke helt uvanlig eksempel er en pasient som utskrives fra sykehus med et antipsykotikum. Primærlegen eller poliklinikken ønsker å kvalitetssikre den medikamentelle behandlingen og får utført en serumkonsentrasjonsmåling. Resultatet ligger over «referanseområdet», dosen reduseres, pasienten blir etter hvert dårligere og søkes innlagt på nytt. Innleggelsesgrunnen oppgis typisk å være «tilbakefall», ikke utilstrekkelig medisinering.

Den rådende praksis for innsending $\mathrm{av}$ serumprøver synes i alt overveiende grad å dreie seg om pasienter som bruker psykofarmaka i ordinære doser uten spesielle eller uventede bivirkninger. Den mest uheldige konsekvensen er sannsynligvis at en serumkonsentrasjon innenfor «referanseområdet» blir et argument for at pasienten er tilfredsstillende medisinert, selv om det slett ikke behøver å være tilfelle. Laboratoriene synes på sin side å anta at det finnes et terapeutisk område for alle psykofarmaka og at dette vinduet ligger i eller i nærheten av det «referanseområdet» de selv har definert. Følgene kan bli både selvforsterkende og villedende. Gitt at pasienter som får målt serumkonsentrasjoner utenfor «referanseområdet» får justert medikamentdosen, vil med tiden serumkonsentrasjonene i økende grad havne i «referanseområdet», avvikene bli færre og standardavvikene helt sikkert mindre. «Referanseområdet» vil trolig bli smalere, bevege seg mot det numeriske tyngdepunktet av målingene og sannsynligvis bli mer og mer misvisende i forhold til den enkelte pasient. Dette er imidlertid basert på antakelser og inntrykk. Det finnes så godt som ingen forskning som opplyser oss om konsekvenser av psykofarmakologisk terapimonitorering utover det rent deskriptive.

Hva får kolleger til å bestille disse serumanalysene? Det har vært en betydelig utvikling i psykiatrien de siste ti år i retning av at alt skal kvantifiseres. Bruken av såkalte verktøy som skal kunne tallfeste symptomer og lidelse har skutt i været. Legers vurdering og kliniske skjønn er mindre dokumenterbart og lettere tilgjengelig for kritikk. Det passer godt inn i dette bildet at man også forsøker å tallfeste kvaliteten på den medikamentelle behandlingen. Kan det tenkes at dette forsøket har endt i ren tallmagi?

\section{Pål Gjerden}

pal.gjerden@sthf.no

Psykiatrisk klinikk

Sykehuset Telemark

Ulefossvegen 55

3710 Skien

Oppgitte interessekonflikter: Ingen

Litteratur

1. Nilsen L. Overdoserer antipsykotika. Dagens Medisin 23.2.2009.

2. Refsum H. Frarøver psykiatriske pasienter kvalitetskontroll. Dagens Medisin 11.6.2009.

3. Touw DJ, Neef C, Thomson AH et al. Cost-effectiveness of therapeutic drug monitoring. A systematic review. Ther Drug Monit 2005; 27: $10-7$

4. Mitchell PB. Therapeutic drug monitoring of psychotropic medications. J Clin Pharmacol 2001; 52 45-54S.

5. Bengtsson F. Therapeutic drug monitoring of psychotropic drugs. TDM «Noveau». Ther Drug Monit 2004; 26: 145-51. 